\title{
Socioeconomic and Demographic Characteristics as Predictors for Residents Attitudes Towards Landuse Development: A Study on Fayoum Cities (Urban Sprawl Fringes)
}

\author{
Hany Samy Abu El Ela*
}

\begin{abstract}
Fayoum cities urban growth boundaries have made a lot of fringes. These fringes have got a mixture of residents with varied characteristics and varied behaviors towards environmental aspects and landuse change. Several studies have identified people characteristics of cities outskirts but few studies have successfully discussed the relationship people behavior and landuse decision. This study aims at monitoring the properties of these fringes generally, and in Fayoum cities particularly, the main motivations of people to occupy them, in addition to testing the hypothesis that attitude towards landuse development (LUD) is correlated with residents several characteristics like: length of residence and demographic variables, which can predict future landuse behavior can better understand the impact their choices will have? Using multiple regression, the study found that area, employment, income and education are generally the main predictors of attitude, while applying logistic regression analysis revealed that education, old, employment and owned are the main predictors for residents trends towards preservation of current landuse. The results of the study proved that land owners decisions towards landuse development in Fayoum cities fringes are based primarily on residents' behavioral characteristics, that reflect attitudes depends on their sociodemographic characteristics. [Bul. Soc. Géog. d'Égypte, 2016, 89: 59-90]
\end{abstract}

Key Words: attitude, behavior, landuse development, length of residence, logistic regression.

\section{Introduction}

Urban sprawl phenomena has been widely criticized in both developed and developing countries over the last decade. Critics of sprawl argue that urban expansion leads to an undesirable misused of farmland along with a loss of amenity benefits from open space on the urban fringe. The physical aspects of urban growth are related to land cover, whereas the functional are related to these various types of landuse.

Landuse pattern is determined as a result of a land owner own property interests and to meet his/her own goals. Even though governmental laws constrain the landuse patterns, the land owners retain substantial autonomy to choose appropriate landuse in a variety of ways, with a variety of environmental infringements. Thus, the behavior and attitude of private land owner has an important impact at sustainable development processes.

* Department of Geography, Faculty of Arts, Fayoum University. 
There is no doubt that the population of urban growth fringes are mixed between urban and rural with their varied attitudes and behavior towards landuse. In this context many researchers have examined the differences in environmental attitudes between urban and rural residents (Buttel, 1977; Gray, 1985; Lowe, 1982; McBeth, 1995).

It's important to understand land owners behavior that can explain those conflicts between newcomers and long-time residents reflected in landuses at these fringes and can enable decision maker to formulate programs that allow citizens and governments to more efficiently utilize their time, talent, and financial resources. Furthermore, understanding the land owners behavior helps to formulate landuse policies that will be more relevant to their concerns and thus may be more likely to be successfully adopted (Laubhan, 2001).

This research focuses on scanning landuse patterns at the urban sprawl fringes of Fayoum cities depending on analyzing the population attitudes. It demonstrates people's reasons to live at these areas and tests the hypothesis that landuse patterns correlated with residents attitudes which are motivated by some socioeconomic and demographic characteristics. It investigates the private landuse patterns at the urban sprawl fringes of Fayoum cities from the perspective of land owner attitude and behavior by examining the landuse choices of individual land owners and variables that correlate with those choices (Figure 1).

In addition to its narrower focus, the present paper differs from others by investigating the interaction between these varied kind of population and landuse development (LUD). This approach raises behavioral issue that was not a major factor in the previous studies. It also highlights the urban growth fringes profile of Fayoum cities, then examined the data to gather demographic information about the survey sample using descriptive statistics. In addition to applying some statistical methods (Multiple regression and Logistic regression analysis).

According to the aim of the study, of approximately 2880 households, a sample of 600 was drawn randomly where the data were collected using personal interviews in addition to information collected by observation of the six cities. Also, it is observed that an integrated approach involving remote sensing and GIS technique can be successfully used in this study for choosing the study sample, data management and detecting urban growth boundaries (change detection). On the other hand Statistical Package for the Social Sciences (SPSS) software is applied for achieving correlations and regressions analysis. 


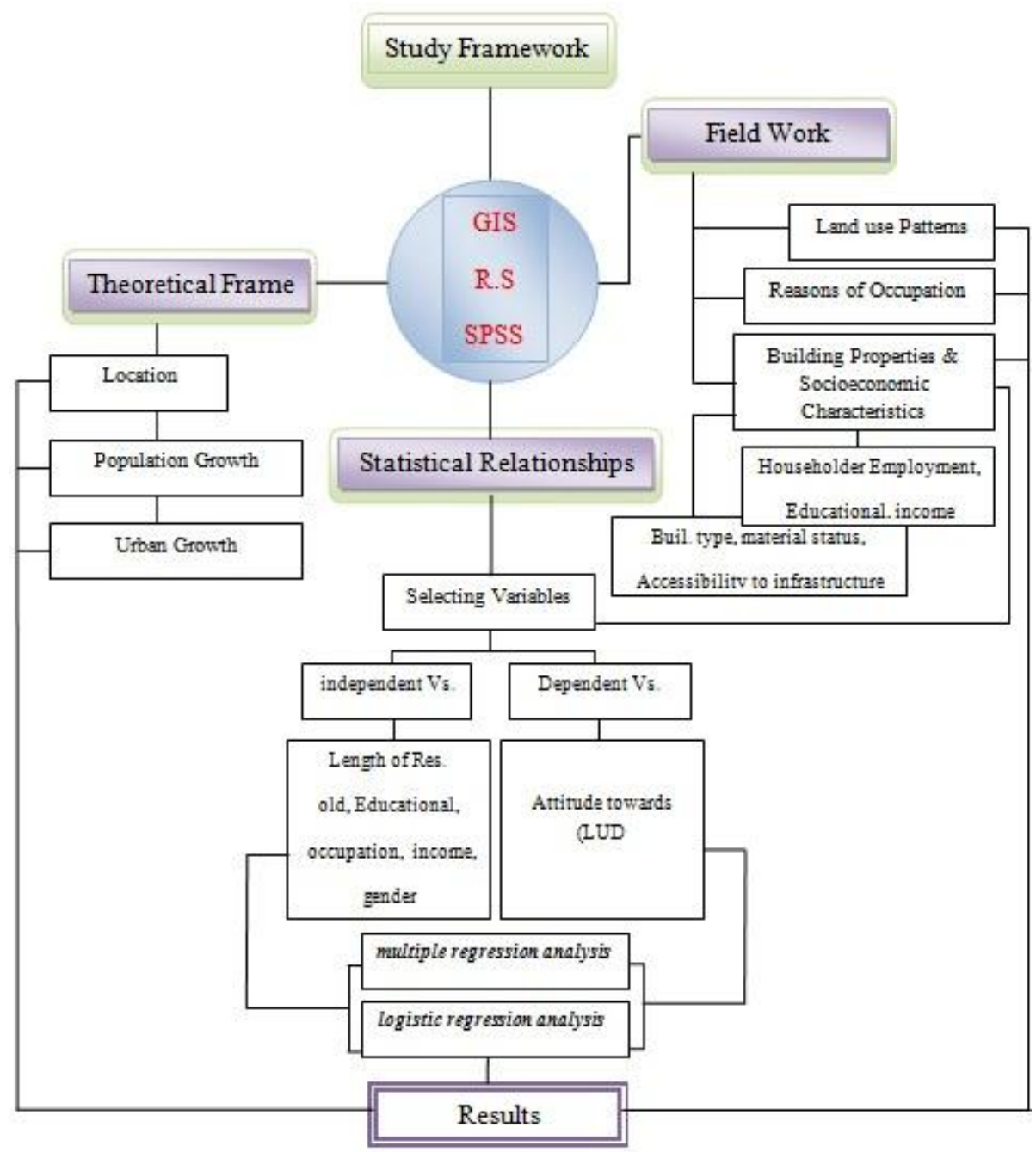

Figure 1. The study framework.

\section{Fayoum Cities: Characteristics of urban growth;}

\subsection{Location and context}

Fayoum governorate is one of the Egyptian governorates. It is located on the Northern Upper Egypt region, which includes three governorates (Fayoum, Beni Suef and Minya). The governorate occupied a natural oasis located in the Western desert at about $90 \mathrm{~km}$ distance southwest of Cairo between $29^{\circ} 10^{\prime}$ and $29^{\circ} 35^{\prime}$ North and $30^{\circ} 20^{\prime}$ and $31^{\circ} 10^{\prime}$ East (Figure 2). The total area of the governorate is estimated to be $6.068 .70 \mathrm{~km}^{2}$. 


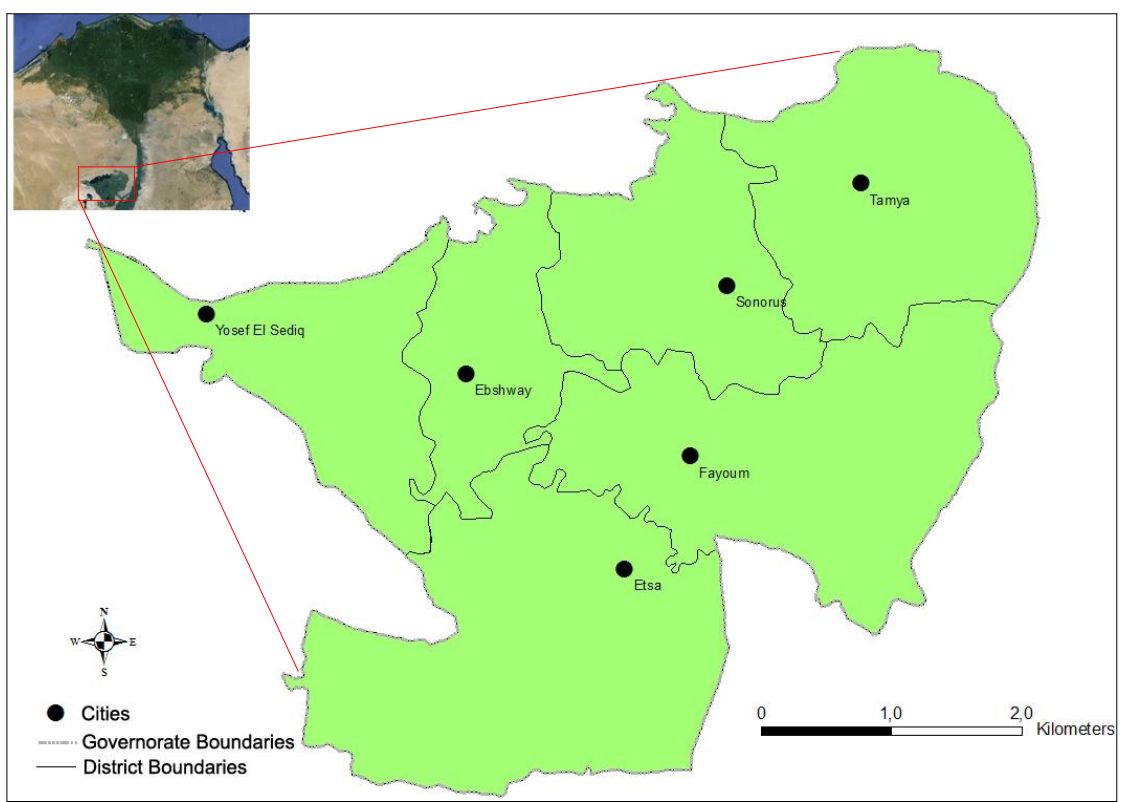

Figure 2. Fayoum Cities Location.

Fayoum general landscape looks like a wide extended circular depression connected to the Nile through Bahr yousef (Safey El Deen, 1999). The fertile soils have their role in creating the appropriate environment for residents to spread on the agricultural land.

Fayoum governorate comprises six administrative districts, which contain six cities. These six cities are characterized by their specific location as they are considered the capitals of these districts where the meeting point of the main transport lines and the public services are there. These cities are Fayoum, Etsa, Sonorus, Tamya, Ebshway, and Yosef El Sediq which dated to 2002, when the administrative decision No. 185 was issued to construct Yosef El Sediq city under subordination of Fayoum province ${ }^{(1)}$. The city established in newly reclaimed desert area northwest of Fayoum including the an old Reclamation village and the newest parts added from the adjacent "Hatim El Taei" area.

\subsection{Population growth}

Population growth has its strong effect on urban growth and so it is logical to find that the greatest gains occurred in highly populated countries where large numbers are added to population day after day.

(1) Fayoum Governorate, Information Center, unpublished data 2002. 
Fayoum cities' population growth was reported through successive census during the last 30 years (CAPMAS 1986-2016 ${ }^{(1)}$ ); Urban population of Fayoum governorate reached 359995 by $23.2 \%$ of the governorate total population in 1986. It has continued to increase, registered 447239 by $22.6 \%$ in 1996 and 565175 by 22.5 in 2006, then increased to 680576 in 2016 population estimating. It was noticed that Fayoum cities' population was increasing continuously with similar yearly increasing rates during the period from 1986 to 2006 (Table 1 and Figure 3).

Whereas It is noteworthy that the annual growth rates of the cities' general population go towards the decrease in recent years. On the other hand This rate cannot be evaluated in the newly established city of Yosef El Sediq.

Table 1. Total population and Growth rates of Fayoum cities according to last year's census. ${ }^{(2)}$

\begin{tabular}{|c|c|c|c|}
\hline City & Year & Population & $\begin{array}{c}\text { Yearly increasing } \\
\text { percentage }(\%)\end{array}$ \\
\hline \multirow{4}{*}{ Fayoum } & 1986 & 213070 & - \\
\hline & 1996 & 260830 & 2.2 \\
\hline & 2006 & 315940 & 2.1 \\
\hline & 2016 & 375969 & 1.9 \\
\hline \multirow[t]{4}{*}{ Etsa } & 1986 & 27664 & - \\
\hline & 1996 & 37146 & 3.4 \\
\hline & 2006 & 47189 & 2.7 \\
\hline & 2016 & 58514 & 2.4 \\
\hline \multirow[t]{4}{*}{ Sonorus } & 1986 & 55187 & - \\
\hline & 1996 & 68442 & 2.4 \\
\hline & 2006 & 82148 & 2.0 \\
\hline & 2016 & 100221 & 2.2 \\
\hline \multirow[t]{4}{*}{ Tamya } & 1986 & 29238 & - \\
\hline & 1996 & 38383 & 3.1 \\
\hline & 2006 & 49385 & 2.9 \\
\hline & 2016 & 61731 & 2.5 \\
\hline \multirow[t]{4}{*}{ Ebshway } & 1986 & 34636 & - \\
\hline & 1996 & 41972 & 2.1 \\
\hline & 2006 & 54853 & 3.1 \\
\hline & 2016 & 68018 & 2.4 \\
\hline \multirow[t]{4}{*}{ Yosef El Sediq } & 1986 & 0 & - \\
\hline & 1996 & 0 & The city established in 2002 \\
\hline & 2006 & 15660 & - \\
\hline & 2016 & 16123 & 0.9 \\
\hline
\end{tabular}

(1) CAPMAS: The first population estimation for 2016.

(2) CAPMAS: Reports of 1986, 1996, 2006 and the first population estimation for 2016. 


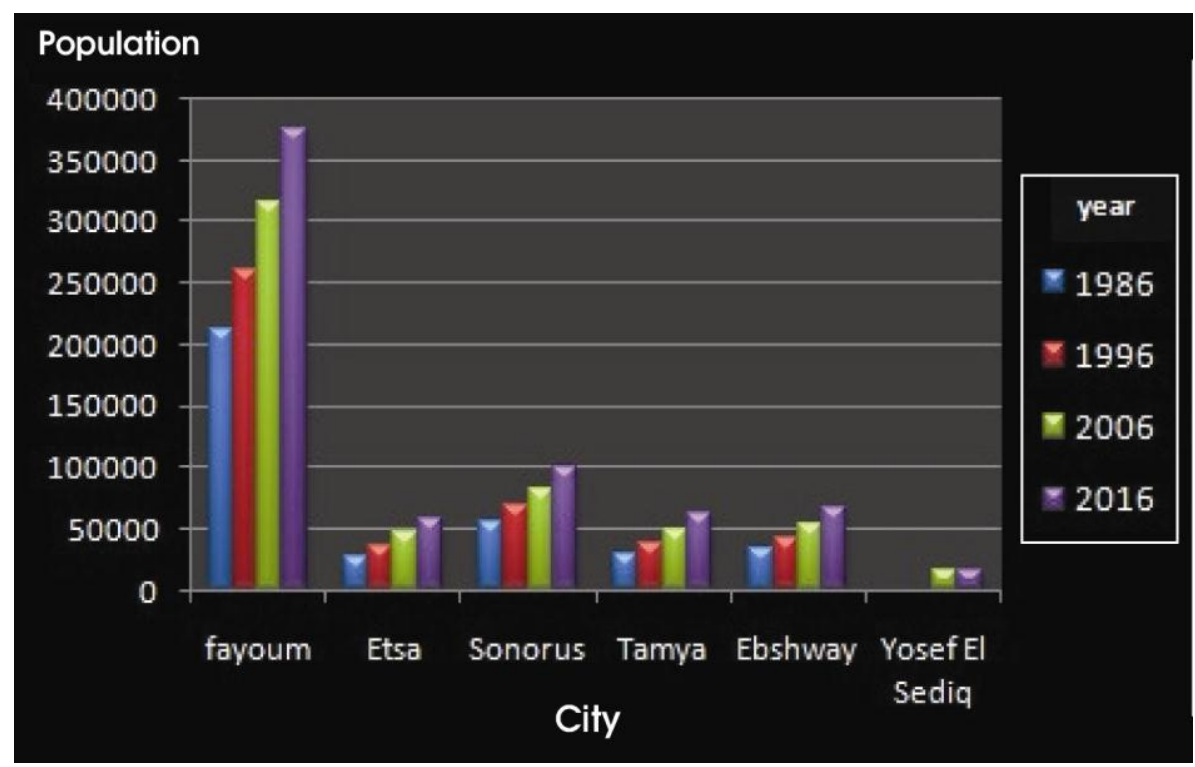

Figure 3. Population growth of Fayoum cities 1986-2016.

The detailed image of 2016 population estimation shows that Fayoum city represent the first rank in terms of population size as it has 55.2 percent of Fayoum governorate total urban population. Sonorus comes at the second rank by $14.7 \%$, Then Ebshway (10.0\%) while Yosef El Sediq city registers the fewest rank $(2.4 \%)$.

\subsection{Urban growth}

With the continuous development of population in Fayoum cities, all of them suffered from an urban encroachment on agricultural land (Figure 4 a and $b$ ) in order to accommodate this population growth. This Urban growth has been occurred in several different stages according to the variation in population growth and some other effects such as the government legislation governing building on agricultural land.

Figure (5) demonstrates that Fayoum cities (Except for Yosef El Sediq) have faced an urban growth during last years that resulted in the restructuring their external borders and the emergence of outer fringes with their varied properties. On the other hand, boundaries of Yosef El Sediq that established in newly reclaimed desert area seems to be stable Since 2002 so it isn't included. 


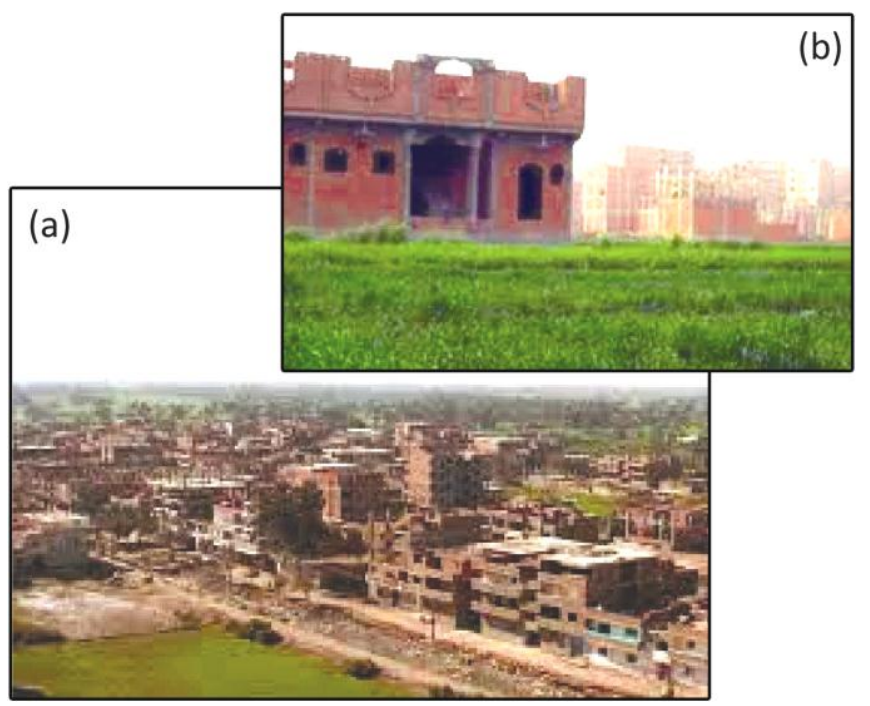

Figure 4. Urban sprawl on arable land in Fayoum City.
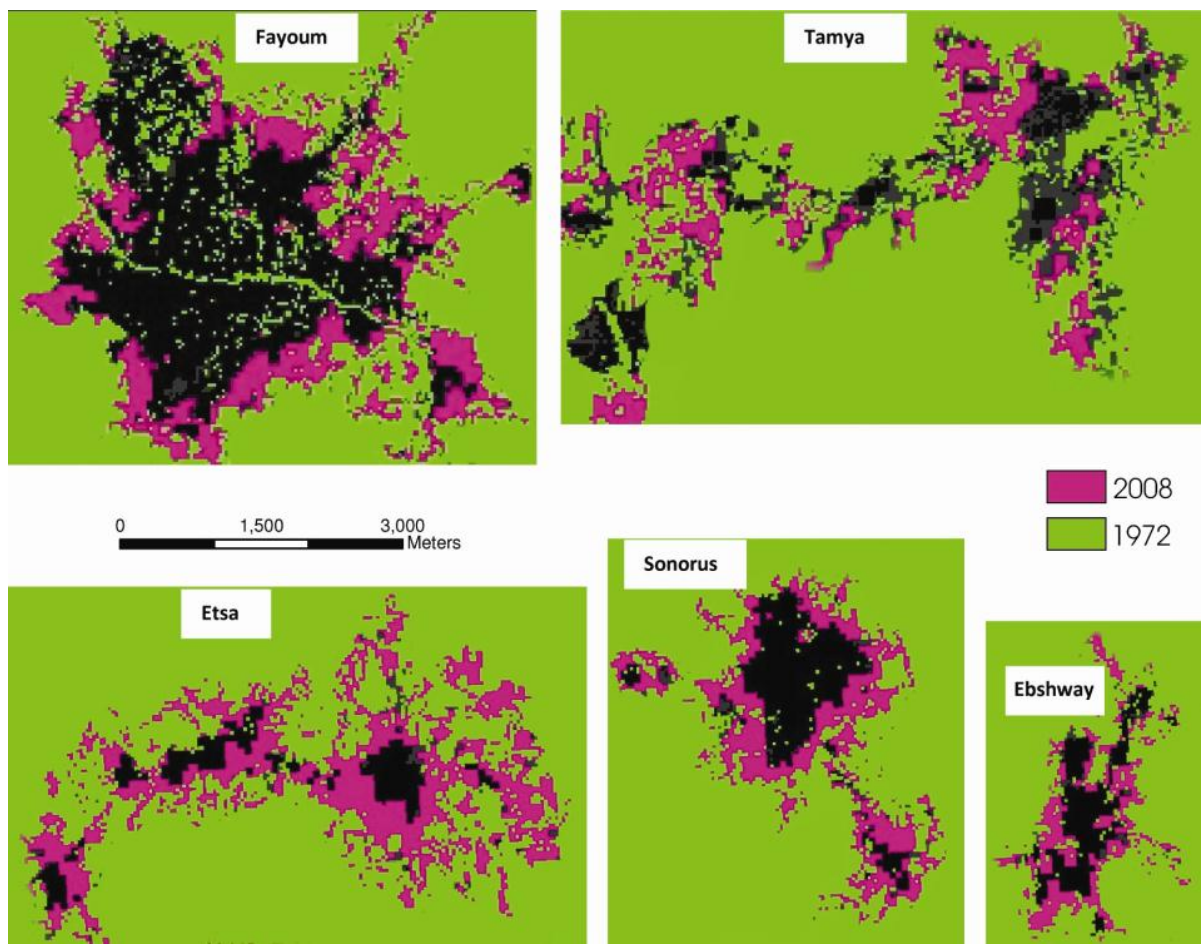

Figure 5. Fayoum cities urban growth from 1972 to 2008 based on satellite imageries.

Source: LANDSAT; Projection: GCS WGS84. 


\subsection{Building properties and Socioeconomic conditions}

Socio-economic developments at macro level impact on the demand for residential, industrial and commercial locations, while the availability of suitable locations and the actual spatial configuration in turn impact on the overall socio-economic developments (Hedwig van Delden, 2011). Some present socio economic profile of dwellers as a vivid picture of factors such as caste, religion, education, health status and living environment of the family, type of the house, occupation and annual income of the family (Research scholar, 2013).

As a purpose of this study a field work was conducted to examine households' socioeconomic conditions (Appendix 1). A questionnaire form was prepared and applied on Fayoum cities urban growth fringes. It consisted of two main sections and asked about; (1) built unit properties (e.g., the building type, building material, condition and accessibility to infrastructure and services); (2) the family head's socioeconomic status regarding desirable locations.

Two main groups of factors are presented here: built unit properties and family head's socioeconomic status.

To sum up, the survey revealed some important facts and issues:

- Urban growth fringes of Fayoum cities are generally characterized by the predominance of the rural houses in varying proportions, built in loam bricks at the majority of them except for Yosef El Sediq that has most of its buildings of rural types built in Lime bricks (Figures 6 and 7).

- Most of these fringes studied buildings have good status due to their modern construction dates and are well connected to the water and the drainage networks except for Yosef El Sediq that has $49 \%$ of its sample buildings unconnected to the water network and $90 \%$ of them unconnected to the drainage network (Figures 8 and 9).

Because the employment status is a basic indicator of economic soundness of households, the study scanned the family head's employment status. It demonstrated that Agricultural activities prevail, especially in Yosef El Sediq fringes (26\% of the total employment) as well as in Fayoum (39\%). Business is the most widespread activities in Etsa fringes. In addition, these areas includes other activities in varying proportions (such as: civil servants, craftsmen, retired employees and some informal employment and on-working people (Figure 10). 

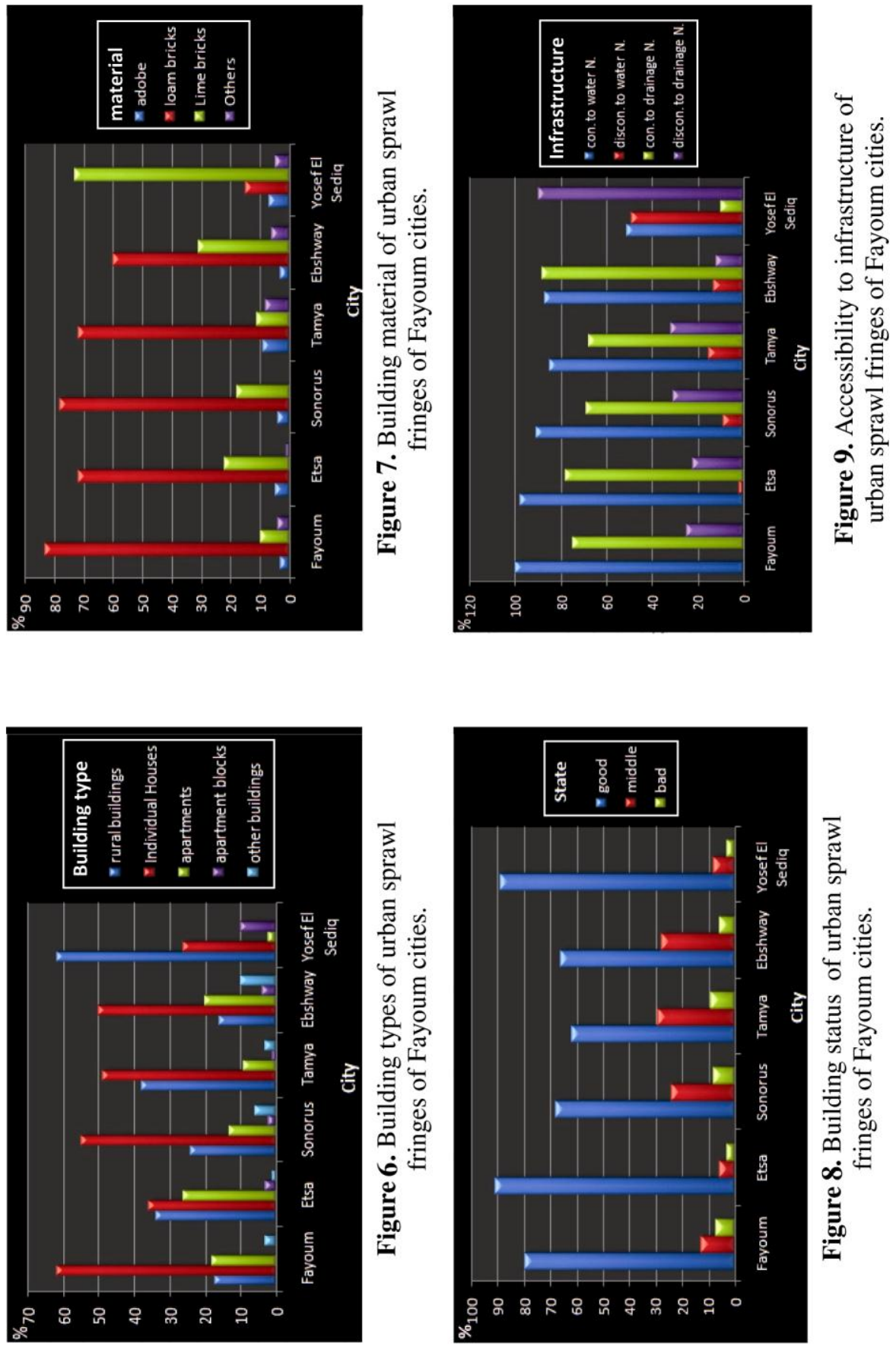
It's observed that a great portion of the family heads were illiterate. On the other hand, Yosef El Sediq has a low percentage of illiterate people as a result of some legislation which obliges the owner of the reclaimed land be capable of reading and writing. There is also a prevalence of less than secondary qualifications at these fringes in addition to a number of people who have other qualifications (Figure 11).

It is worth mentioning that the great portion of the sample household of Fayoum cities has monthly income of 1000 to 2500 Egyptian pounds (Table 2).

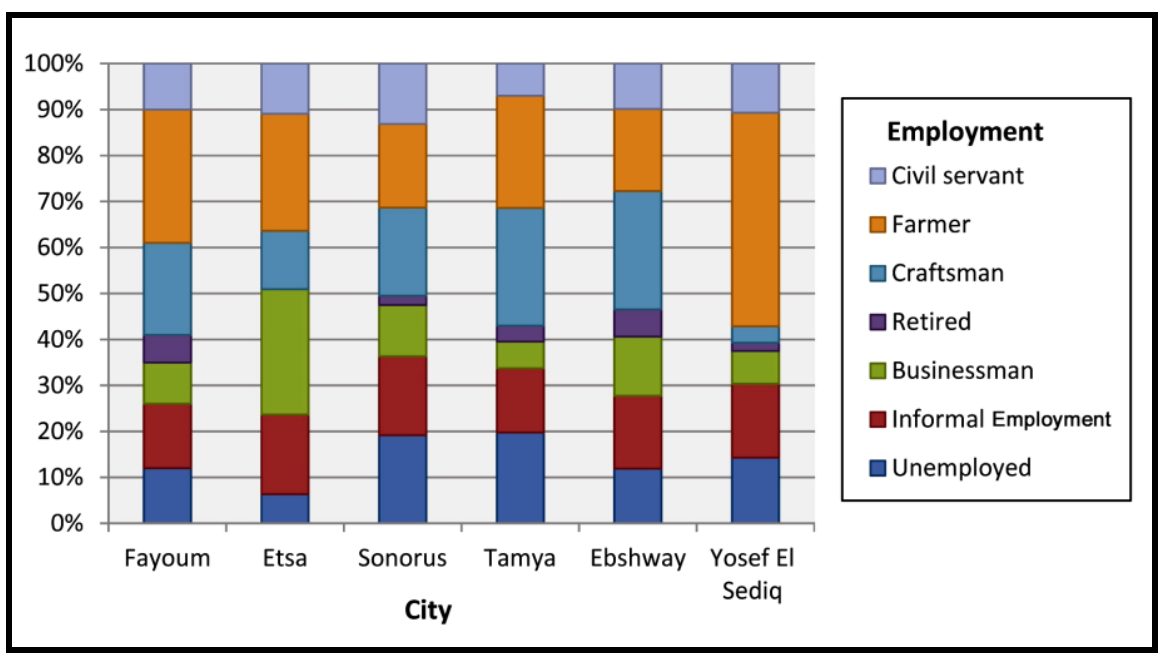

Figure 10. Employment distribution in urban sprawl fringes of Fayoum cities.

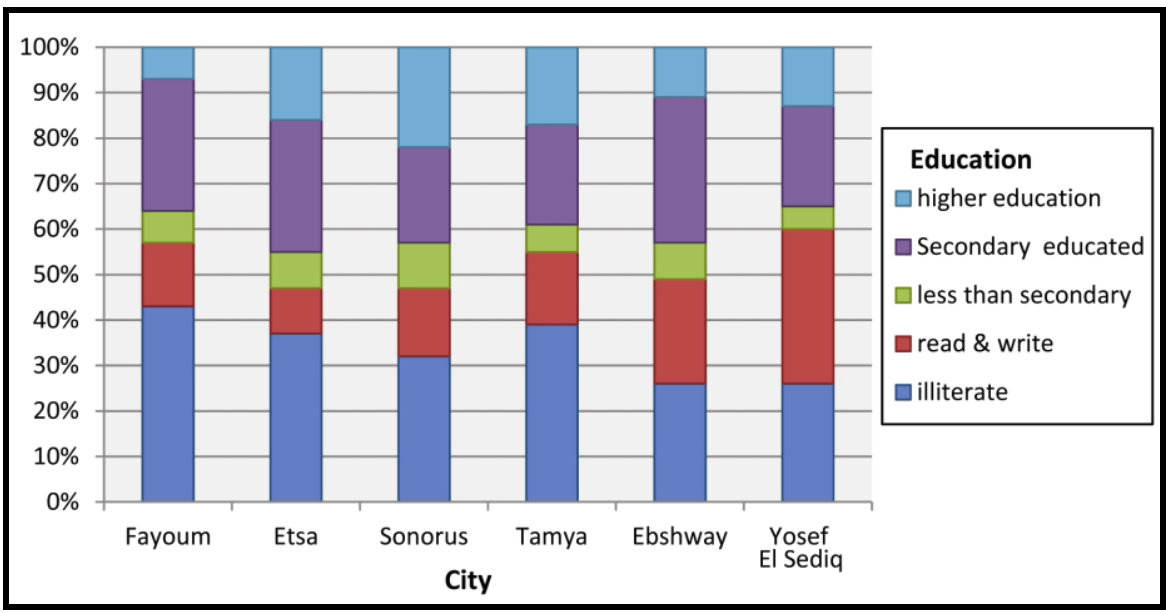

Figure 11. Educational status in urban sprawl fringes of Fayoum cities. 
Table 2. The income distribution of the Sample Households of Fayoum cities urban growth fringes.

\begin{tabular}{|c|c|c|c|c|c|c|c|}
\hline $\begin{array}{c}\text { Monthly } \\
\text { Income }\end{array}$ & Fayoum & Etsa & Sonorus & Tamya & Ebshway & $\begin{array}{c}\text { Yosef EI } \\
\text { Sediq } \\
\end{array}$ & $\begin{array}{c}\text { Mean } \\
\% \\
\end{array}$ \\
\hline$<£ 500$ & 15 & 11 & 17 & 14 & 12 & 18 & \multirow{2}{*}{34} \\
\hline$£ 500-$ & 24 & 20 & 19 & 21 & 13 & 20 & \\
\hline$£ 1000-$ & 26 & 21 & 23 & 30 & 31 & 43 & \multirow{3}{*}{56} \\
\hline$£ 1500-$ & 13 & 14 & 17 & 15 & 24 & 12 & \\
\hline$£ 2000$ - & 11 & 15 & 16 & 11 & 9 & 4 & \\
\hline$£ 2500+$ & 11 & 19 & 8 & 9 & 11 & 3 & 10 \\
\hline Total \% & 100 & 100 & 100 & 100 & 100 & 100 & 100 \\
\hline
\end{tabular}

Source: Field survey, 2015.

\section{Meanings of Attitude and Behavior}

Since Rosenberg defined attitude in the social psychology as three component concept: feeling, cognitive and behavioral which make decisions (Rosenberg, 2010) many studies and theories discussed these three components and the interrelations between them. It's important to discriminate between the general attitudes and some attitudes towards particular action to be handled. On the other hand It can be said that attitudes may control behaviors.

Some scientists have reported that there may be no relationship between attitude and Behavior at all, But others tried to search for elements that will tighten up these relation. They have concluded that attitude often plays as a predictor of behavior (Eiser, 1988).

Concerning the behavior and its impact on the environment, the Researchers examine that at many studies (but not exclusively landuse). They have developed models that describe the correlation between environmental attitudes and environmental behavior (Vaske, 1999), (Scott, 1994) and (Fortman, 1990).

It's important to say that although the complex concept of the attitude, researchers give a relative weight to the behavioral intention aspects of the attitude concept than those other two components.

Although Some scientists often consider that one type of behavior is superior to another as a responsible environmental behavior. For example, it is more environmentally responsible to recycle than to not recycle or so. Others displace that by the phrase "environmentally significant behavior" (Stern, 2000). Suffice it to say, understanding the motivations of landuse classes, requires first the awareness of land owners behavior. 


\section{Rural/Urban Differences}

The starting point towards understanding landuse decisions is to examine attitudes by contrasting the urban and rural residents at the city urban growth fringes. As there is no clear differences between what is very rural and what is very urban, researchers devoted much time exploring the differences between "rural" and "urban" society. Whereas much of the definitional approach sought to find differences in sociodemographic, attitudinal, and cultural variables, an important finding was that rural and urban were less polarities or elements of a dichotomy than stations along a continuum (William H. Friedland, 2002). Others strove to determine factors of spatial differentiation between them as follow:

The first focuses on geographical properties (Braun, 2007)and the second indicates to the certain activities (Venables, 1996), whereas the third goes to the urban-biased and industry focused policies (Adelman, 2007).

From an environmental perspective, the study of differences in attitudes between urban and rural residents generally and at the city fringes specially are at a crossroads due to their varied social trends. There are many studies at the literature that investigated these differences depending on examining different residential groups at rur/urban spots (McBeth, M.K. 1995 op. cit.), (Lowe, 1982) and (Tremblay, 1978).

Further, scientists have developed some theories explaining the ways of measuring environmental attitudes of both rural and urban people at the urban/rural fringes. They used factors of "growth, consumption, sustainability and values of aesthetics and ecosystem" in their correlating to specific demographic groups (Vaske 1999 op. cit.). In this context there are two main theories explaining these differences: (1) the Extractive Resource Commodity theory that indicates that rural residents value natural resources for economic potential rather than for their inherent aesthetics that reflect a lower level of environmental concern than urban residents (Tremblay, 1978 op. cit.) and (2) the Conservative Non-Elite theory that reports that rural people are lower than urban people in income, less educated, older, and more politically conservative. Theory also explains differences in environmental concern between the urban elite and the urban non-elite residents. It posits that the environmental attitudes are not only attributable to place of residence, but also to other demographic factors that tend to be found as characteristics of rural communities. 


\section{Investigating the Relationship between Residents Attitudes and Landuse Patterns}

According to the main goal of this study, it relies mainly on data from surveys and interviews of individual land owners (family providers') of Fayoum cities urban growth fringes. Beside demographic and socioeconomic data gathered. Using SPSS software, descriptive statistics were performed first to examine gathered data and have a general idea of factors image. Then, the main variables were chosen and the correlations function was implemented to investigating relationships between variables. The hypotheses; satisfaction with current landuse allocation and preservation of current landuse were been tested.

\subsection{Variables selected for the study:}

To examine the individual land owners attitude and behavior in correlation to the landuse choices, some variables have emerged from the literature that are useful to include in the multiple such a regression approach. These variables can be classified as dependent and independent variables (Table 3):

\subsubsection{Independent variables:}

As it shown, length of residence have been included as an independent variable in order to show how long a person has been lived in the study area and past opportunities to participate in development (Fortman, L. and J. Kusel. 1990. op.cit.) Furthermore, some researchers found that some sociodemographic characteristics such as age, education, occupation, income and gender have their impact on in the environmental attitudes towards the landuse (Koontz, 1999) So "Length of residence" and "socioeconomic and demographic characteristics" are included to demonstrate their potential effects on people attitude towards landuse developments.

\subsubsection{Dependent variables:}

According to psychology literature, the population attitude moves the environmental behavior (Fulton, 1996), So it has been included as a main dependent variable at this study. It's noted that there are different behavioral responses of attitudes towards the varied environmental topics (Stern, 2000), thus, this study deliberately depends on the responses to questions deal particularly with people's attitudes towards landuse issue (see Appendix 1) investigating their attitude towards development, their opinions of landuse development around their homes and their positions of the current landuse types. 
It is noteworthy that there are some other elements based on the literature which play as moderator variables in between the above elements: physical factors and social context are the most important factors (Corraliza, 2000), but they are not considered at this study because there are similarities between them in Fayoum cities.

Table 3. List of the study variables.

\begin{tabular}{|l|c|}
\hline Independent variables & $\begin{array}{c}\text { length of residence, socio-demographic } \\
\text { (age, education, occupation, income and gender) }\end{array}$ \\
\hline Dependent variables & population attitude towards landuse development \\
\hline
\end{tabular}

\section{Results}

The statistical results will be discussed at this section in the following order: first, length of residence variable will be discussed, second the landuse patterns, Third reasons for landuse, Forth attitude towards development, attitude towards development by length of residence, multiple regression using a dependent variable of attitude towards landuse development, behavioral intention towards landuse development and finally will be the logistic regression analysis using preservation of current landuse as a dependent variable.

\subsection{Length of Residence:}

Length of residence had its important to be a main factor that may reflect not only how long a person has been in an area, but also his/her types of attitude towards development (Fortman 1990, op. cit.). Further, length of residence may be used as an indicator to the land area that a resident could own and what types of landuses he/she preferred to occupy it. Although some researchers considered this element had no significant effect in comparison to other demographic and socioeconomic elements on persons' situations towards the area they live in (Smith, 2000). To get the complete profile of the population length of residence, The study sample was split according to the answers to a question: "How long have you lived in this place?". Accordingly, the study sample was spelt into three classes: long-term residents (those who had lived at the place 10 years and more), midterm residents(those who have lived at the place 5 to less than 10 years) and newcomers (who have lived the place less than 5 years). Table (4) shows the percentages of Population Length of residence in Fayoum cities fringes. 
Table 4. Percentages of population Length of residence in Fayoum cities fringes.

\begin{tabular}{|l|c|c|c|}
\hline Cities fringes & $\begin{array}{c}\text { Newcomer } \\
\text { (less than 5 years) }\end{array}$ & $\begin{array}{c}\text { Midterm } \\
\text { (5 to less than 10 years) }\end{array}$ & $\begin{array}{c}\text { Longer-term } \\
\text { (10 years and } \\
\text { more) }\end{array}$ \\
\hline Fayoum & 15.2 & 23.6 & 61.2 \\
\hline Etsa & 19 & 20.2 & 60.8 \\
\hline Sonorus & 14.9 & 23.8 & 61.3 \\
\hline Tamya & 16.5 & 22.6 & 60.9 \\
\hline Ebshway & 14.4 & 21.8 & 63.8 \\
\hline Yosef El Sediq & 9.4 & 7.5 & $83.1^{*}$ \\
\hline
\end{tabular}

* The city established in newly reclaimed desert area in 2002 .

\subsection{Landuse Patterns:}

Land cover and landuse are two concepts used to define land characteristics (Jensen, 2000). Land cover refers to biophysical layers of ground coverings like soil, water, agriculture, forest, grass, and build-up land (Verburg, 2003), Whereas landuse is a cultural concept reflecting the way human beings exploit lands (Gong, 1992). Land allocation to specific uses comes of land owners decisions and reflects their needs and preferences. Land owners usually try to attain possibilities of the place as most as possible. Thus landuse research is an indicator to the interactions between human activities and environmental change. Researchers have conducted many experiments to classify land cover types, then by field work they could separate residential landuses from other landuses within urban areas.

The distribution image of the landuse in Fayoum cities fringes (Figure 12) reflects that there is prevailing of residential non-mixed use generally (between 70 and 85\%). Mixed uses (residential commercial and residential industrial) cover between 4 and 14\% only of landuses. The residentialcommercial uses are highly concentrated in Tamya fringes, whereas the residential-industrial uses depict their high percentage in Ebshway fringes. In comparison, commercial, Industrial and services uses are distributed in a fewer percentages.

\subsection{Various Motivations of Fringes Land Occupancy:}

Due to the varied geographic and socioeconomic characteristics and different preferences of residents' of Fayoum cities urban growth fringes, data collected during fieldwork shows that their motivation to occupy these places with these types of landuse patterns falls into the following categories:

(Except the city of Yosef El Sediq that recently constructed because there is no significant development and agricultural is the dominant job) 
1- Looking for cheaper land for housing; Generally cities' outskirts have several advantages that attract the people from across the regions particularly the lower-middle income groups. Where the price of the land is still reasonable at these outskirts. They have become favored destination for settlers of Fayoum cities. Youth and people whose income is not so high specially whose workplaces are inside the cities or around prefer to live there. As figure (13) shows approximately 29.2 percent of people of the study sample prefer to live there due to that reason. Tamya has the majority of its fringes population belongs to this class of reasons $(35 \%)$ followed by the rest of the cities with the lowest percent of Etsa (22\%).

2- Opportunity to establish an economic project like a small industry or small commercial center; These new settlements areas with their potential opportunities usually attract people who seek to find suitable spots for constructing a small industry or commercial center, specially with their cheaper prices. As noted in the field work, approximately 18.6 percent of these who prefer to live at Fayoum cities' fringes come due to this reason. Accordingly, The highest recorded percent was on the outskirts of Ebshway (25\%), whereas Tamya had the lowest (11\%).

3- Seeking better living conditions; the study proved some people (18\%) come to live in these areas seeking lower pollutants, good climate, and a better quality of life. Fayoum and Tamya samples recorded the highest percents of this category ( $22 \%$ and $19 \%$ respectively).

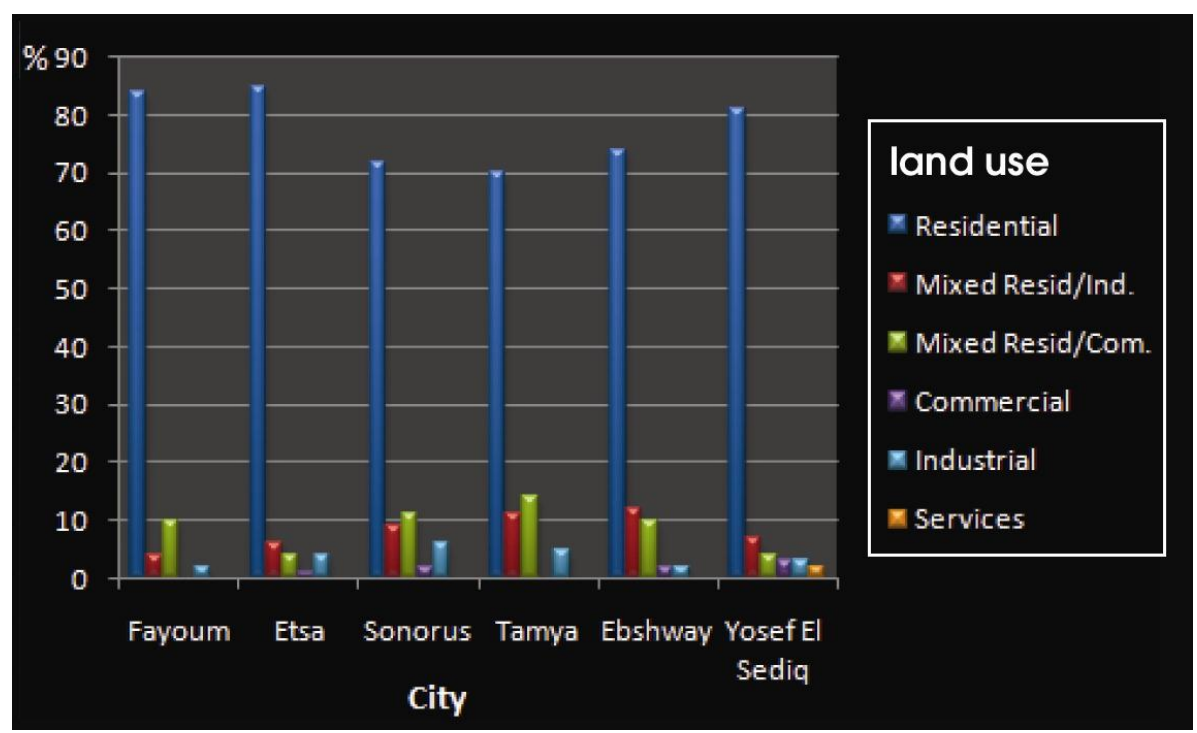

Figure 12. Landuse allocation in urban sprawl fringes of Fayoum cities. 
4- Property investment; The identity of these new settlement areas as cities future landed reserve especially with their cheaper land prices prompted some other people to be interested in buying homes there. They sometimes use them as a residence. Others think that property of these places is very profitable, especially with the tendency of the prices of land and housing within the cities which continue to rise dramatically compared to the prices of land and houses in the outskirts. The high percent of these reasons were found in Etsa (28\%) especially due to the economic high class of some people there (Who migrated to Italy to work and returning to the motherland).

5- Highway access; according to the National Cooperative Highway Research Program (NCHRP) (NCHRP, 1998) and Oregon Department of Transportation Research Group (ODTRG) (Sanchez, 2000), there is significant correlation between highway presence and the development of landuse and it influence land development location decisions. In Fayoum cities fringes, people who preferred to occupy areas which have high way access represented 5.8 percent of the studied sample. They reach 10 percent in Tamya sample but just 2 percent in Etsa.

6- Topography and aesthetic; their average is $7.8 \%$ of the total reasons with rising in places such as Etsa (14\%) and decreased in others, such as Tamya (3\%).

7- Municipal water/drainage availability: This reason presents the lowest average $(4.4 \%)$ with rising in places such as Tamya $(8 \%)$ and decreased in others, such as Etsa (2\%).

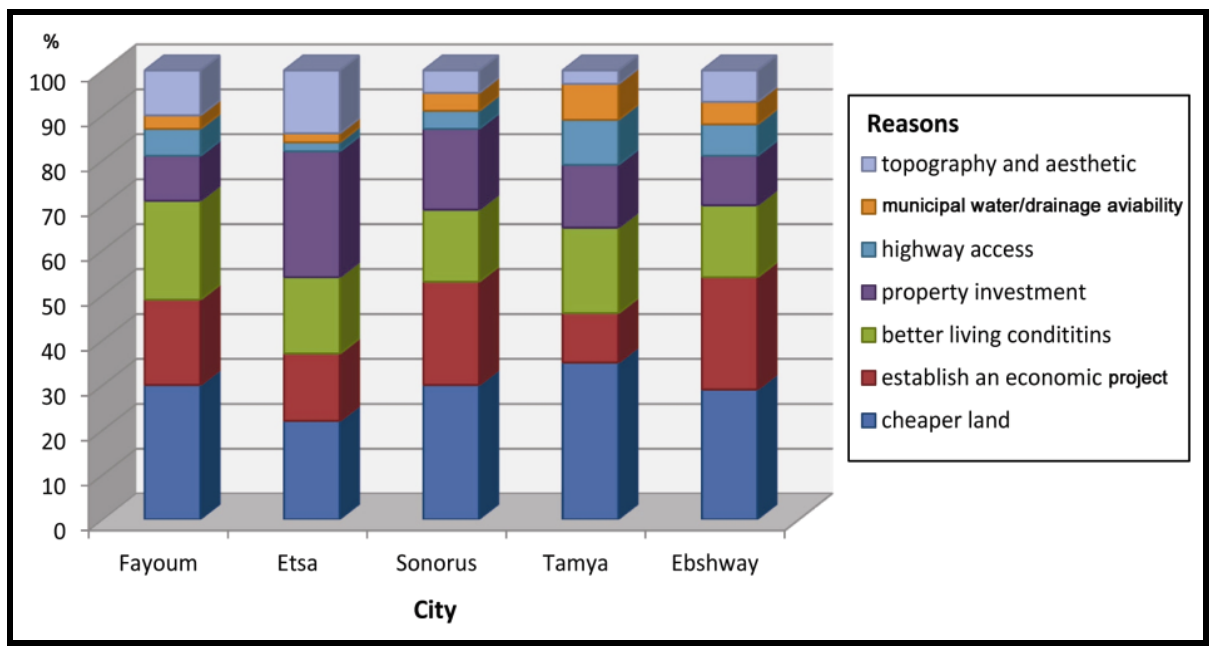

Figure 13. Reasons of landuse in urban sprawl fringes of Fayoum cities. 


\subsection{Attitude towards landuse development}

In order to recognize the land owners attitude towards landuse development, the questionnaire form (Appendix 1) has included an indicator question:" How do you feel about the amount of developed land (for example, residential, commercial and other uses) that currently exist within approximately 1sq. kilometer of this parcel?". The available answers ranged from "I feel that there is too much developed land" to "I feel that there is too little developed land", whereas some answers were "I don't know". As table (5) reveals, people who feel that there is too much developed land (strongly anti-development) represented the largest category of these areas' residents (with the average of 39.8\%). The category of people who feel that it is the right amount of developed land came next with average of $26.4 \%$. As the table shows, Proportions of responses vary between different cities, as the answer with I feel that there is too little developed land (strongly ask for development) represents the lowest average $(3.8 \%)$.

Table 5. Land owners attitude towards landuse development.

\begin{tabular}{|c|c|c|c|c|c|c|c|}
\hline $\begin{array}{c}\text { Attitude Towards } \\
\text { Development }\end{array}$ & 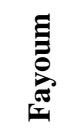 & 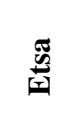 & $\stackrel{n}{\Xi}$ & 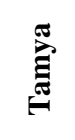 & 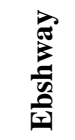 & 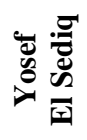 & 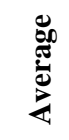 \\
\hline $\begin{array}{l}\text { Too much } \\
\text { developed land }\end{array}$ & 44.3 & 40.4 & 43 & 39.5 & 44.2 & 27.6 & 39.8 \\
\hline $\begin{array}{l}\text { Probably too much } \\
\text { developed land }\end{array}$ & 20.5 & 19.2 & 21.2 & 22.6 & 21.6 & 15.4 & 20.1 \\
\hline $\begin{array}{l}\text { The right amount of } \\
\text { developed land }\end{array}$ & 26.8 & 25 & 24.1 & 27 & 24.5 & 30.9 & 26.4 \\
\hline $\begin{array}{l}\text { Probably too little } \\
\text { developed land }\end{array}$ & 2.1 & 5.9 & 4.8 & 4.2 & 2.5 & 11.9 & 5.2 \\
\hline $\begin{array}{l}\text { Too little developed } \\
\text { land }\end{array}$ & 2.5 & 3.5 & 2.9 & 2.5 & 2.8 & 8.4 & 3.8 \\
\hline Don't know & 3.8 & 6 & 4 & 4.2 & 4.4 & 5.8 & 4.7 \\
\hline Total & 100 & 100 & 100 & 100 & 100 & 100 & 100 \\
\hline
\end{tabular}

The more detailed results of attitude towards development according to the length of residence demonstrate that there is not a consistent attitude towards development. Long term residents represented $(36.5 \%)$ the most percentages of people who felt there was too much developed land followed by midterm $(31.5 \%)$ and newcomers (24.3) respectively. Long-term residents 
came first also compared to the other resident groups with the high response (40.1\%) to the question "I feel that there is the right amount of development" followed by newcomers (38.9\%) and midterm residents (34.3\%). On the other hand, there is a varied small percentages of residents groups their responses were "too little" or "probably too little developed land" (Table 6).

Table 6. Land owners attitude towards landuse development by length of residence.

\begin{tabular}{|l|c|c|c|}
\hline \multicolumn{1}{|c|}{ Attitude Towards Development } & Long-term & Midterm & Newcomer \\
\hline Too much developed land & 36.5 & 31.5 & 24.3 \\
\hline Probably too much developed land & 15.4 & 21.8 & 27 \\
\hline The right amount of developed & 40.1 & 34.3 & 38.9 \\
\hline Probably too little developed land & 2.3 & 7 & 4.6 \\
\hline Too little developed land & 3.2 & 1.1 & 2.8 \\
\hline Don't know & 2.5 & 4.3 & 2.4 \\
\hline Total & $\mathbf{1 0 0}$ & $\mathbf{1 0 0}$ & $\mathbf{1 0 0}$ \\
\hline
\end{tabular}

\subsubsection{Multiple regression analysis}

SPSS multiple regression analysis was implemented using a dependent variable of attitude towards landuse development that are the responses of the previous question: "How do you feel about the amount of developed land (for example, residential, commercial and other uses) that currently exist within approximately 1sq. kilometer of this parcel?" which are recorded into a scale type from 1 to 5 with choice (Don't know) deleted. Gender, education, old, employment, income and owned area considered as independent variables. The model is useful for predicting the dependent variable attitude approximately. The results of the analysis shows that generally, owned area, income, employment and education are significant at 0.05 level (Figure 14a). The detailed results reveal that there is a statistical significance of owned area at the .05 level in all of Fayoum cities fringes. Employment comes as a significant variable in all cities fringes except Etsa where replaced by income. Education also comes as a significant variable in Fayoum, Sonorus and Ebshway (Figure 14 b, c, d, $\mathrm{e}, \mathrm{f}$ and $\mathrm{g})$. 


\section{Coefficients $^{\mathrm{a}}$}

\begin{tabular}{|c|c|c|c|c|c|c|c|c|}
\hline \multirow[b]{2}{*}{ 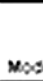 } & & \multicolumn{2}{|c|}{ Unstandardaed Coqnxieros } & \multirow{2}{*}{$\begin{array}{c}\begin{array}{c}\text { Standargiged } \\
\text { Coencipes }\end{array} \\
\text { Beta }\end{array}$} & \multirow[b]{2}{*}{1} & \multirow[b]{2}{*}{ 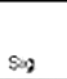 } & \multicolumn{2}{|c|}{$950 \times$ Confisperce interval for $B$} \\
\hline & & $\mathrm{B}$ & Std Erroe & & & & Lowet Bound & Uppet Bound \\
\hline \multirow[t]{7}{*}{1} & (Constanto & .506 & 587 & & .863 & 380 & .1671 & 658 \\
\hline & Gender & 038 & $3 \mathbf{4} 8$ & 008 & 110 & 913 & .652 & 728 \\
\hline & edu & 397 & 105 & 322 & 3.765 & 002 & 188 & 606 \\
\hline & as & .010 & 010 & .076 & $\cdot 986$ & 327 & .031 & 010 \\
\hline & Emgloymant & 420 & 112 & 293 & 3760 & $\infty 08$ & 198 & 642 \\
\hline & income & 000 & 000 & 128 & 1553 & 124 & 000 & 001 \\
\hline & area & 011 & 004 & 247 & 2761 & $\infty$ & 003 & 019 \\
\hline
\end{tabular}

a Dependent Variable: Preservation of current landuse.
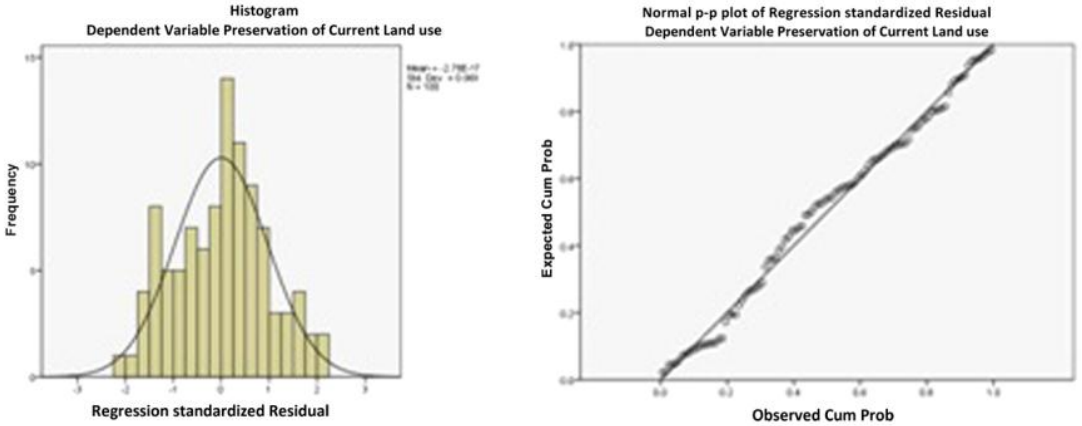

Figure 14a. Multiple regression analysis with attitude as the dependent variable in urban sprawl fringes of Fayoum cities.

\section{Coefficients $^{\mathrm{a}}$}

\begin{tabular}{|c|c|c|c|c|c|c|c|c|}
\hline \multirow{2}{*}{\multicolumn{2}{|c|}{ Model }} & \multicolumn{2}{|c|}{ Unstandardized Coefficients } & \multirow{2}{*}{$\begin{array}{c}\begin{array}{c}\text { Standardized } \\
\text { Coefficients }\end{array} \\
\text { Beta }\end{array}$} & \multirow[b]{2}{*}{$\mathrm{t}$} & \multirow[b]{2}{*}{ Sig. } & \multicolumn{2}{|c|}{$95.0 \%$ Confidence Interval for $B$} \\
\hline & & $B$ & Std. Error & & & & Lower Bound & Upper Bound \\
\hline \multirow[t]{7}{*}{1} & (Constant) & -.495 & .262 & & -1.889 & .059 & -1.009 & .020 \\
\hline & Gender & .148 & .149 & .034 & .998 & .319 & -.143 & .440 \\
\hline & edu & .227 & .044 & .178 & 5.128 & .005 & .140 & .315 \\
\hline & old & -.004 & .004 & -.029 & -.858 & .391 & -.013 & .005 \\
\hline & Employment & .280 & .050 & .189 & 5.576 & .004 & .181 & .379 \\
\hline & income & .000 & .000 & .185 & 5.145 & .003 & .000 & .001 \\
\hline & area & .016 & .002 & .347 & 9.387 & .001 & .012 & .019 \\
\hline
\end{tabular}

a Dependent Variable: Preservation of current landuse.

$$
\text { Histogram }
$$
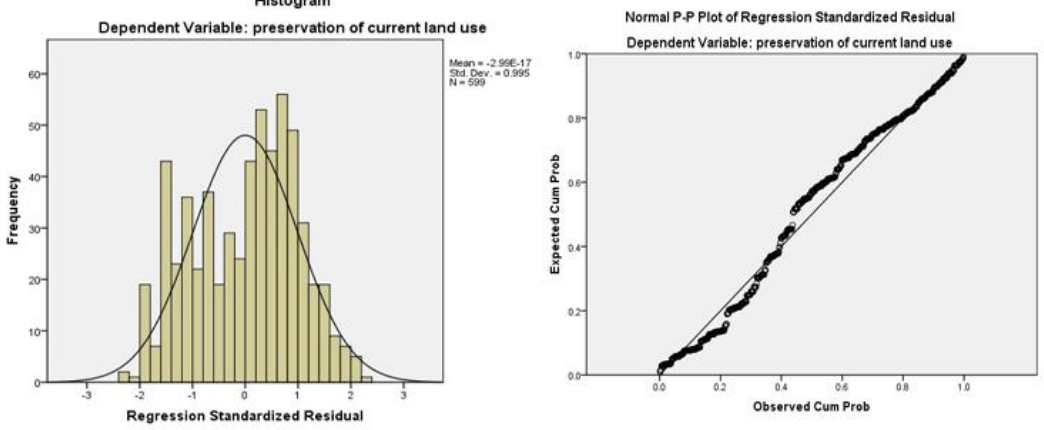

Figure 14b. Multiple regression analysis with attitude as the dependent variable in urban sprawl fringes of Fayoum city. 


\section{Coefficients $^{\mathrm{a}}$}

\begin{tabular}{|c|c|c|c|c|c|c|c|c|}
\hline \multirow[b]{2}{*}{ MOS: } & & \multicolumn{2}{|c|}{ Uentandardiced Coarfxipes } & \multirow{2}{*}{$\begin{array}{c}\text { Standbedoed } \\
\text { Copticients } \\
\text { Bers }\end{array}$} & \multirow[b]{2}{*}{1} & \multirow[b]{2}{*}{ sig } & \multicolumn{2}{|c|}{$950 \%$ coefidence leorral soe 8} \\
\hline & & 8 & Std Erroe & & & & Lower Boung & Upper Bound \\
\hline \multirow[t]{7}{*}{1} & $\langle$ Constaro & 688 & 755 & & 908 & 366 & .813 & 2185 \\
\hline & Genst: & 150 & 393 & 033 & 381 & 704 & .631 & 931 \\
\hline & tos & .050 & 131 & .033 & $\cdot 378$ & $70 B$ & -311 & 211 \\
\hline & old & .015 & 013 & $\cdot 101$ & .1 .155 & 251 & .041 & 011 \\
\hline & Emplopment & $\cos 8$ & 129 & 047 & 529 & 398 & .188 & 325 \\
\hline & income & $\infty$ & 000 & 205 & 2196 & 031 & 000 & $\infty 01$ \\
\hline & sea & 019 & 004 & 433 & 4584 & 020 & 011 & 028 \\
\hline
\end{tabular}

a Dependent Variable: Preservation of current landuse.
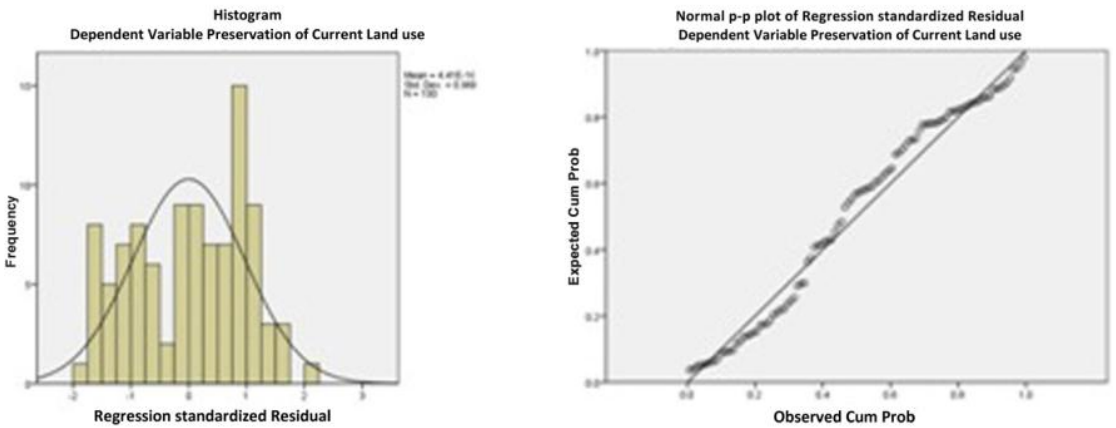

Figure 14c. Multiple regression analysis with attitude as the dependent variable in urban sprawl fringes of Etsa city.

Coefficients $^{\mathrm{a}}$

\begin{tabular}{|c|c|c|c|c|c|c|c|c|}
\hline \multirow{2}{*}{\multicolumn{2}{|c|}{ Mogel }} & \multicolumn{2}{|c|}{ Unstandardced Coetrcients } & \multirow{2}{*}{$\begin{array}{c}\text { Standardeed } \\
\text { Coencients } \\
\text { Bets }\end{array}$} & \multirow[b]{2}{*}{1} & \multirow[b]{2}{*}{$\mathrm{seg}$} & \multicolumn{2}{|c|}{$95.0 \%$ Confidence inatral for 8} \\
\hline & & B & Sss Ertor & & & & Lowet Bound & Upper Bound \\
\hline \multirow[t]{7}{*}{1} & (Constanto & .923 & 639 & & .1 .445 & 152 & -2.192 & .346 \\
\hline & Gender & 150 & 369 & 033 & .06 & 688 & .583 & 883 \\
\hline & osu & 282 & .102 & 234 & 2.771 & $\infty$ & 000 & 484 \\
\hline & old & $\infty 000$ & 011 & 003 & .038 & 970 & .021 & .021 \\
\hline & Emstomment & 352 & .125 & 237 & 2812 & .006 & 108 & 601 \\
\hline & income & $\infty 00$ & .000 & 204 & 2307 & .023 & 000 & 001 \\
\hline & stea & 014 & .004 & 324 & 3.545 & .001 & .008 & .022 \\
\hline
\end{tabular}

a Dependent Variable: Preservation of current landuse.
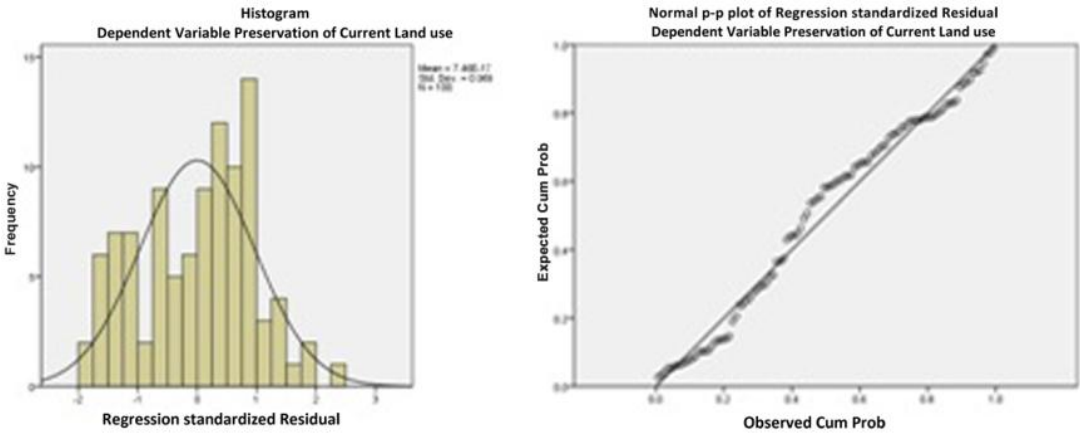

Figure 14d. Multiple regression analysis with attitude as the dependent variable in urban sprawl fringes of Sonorus city. 


\section{Coefficients $^{\mathrm{a}}$}

\begin{tabular}{|c|c|c|c|c|c|c|c|c|}
\hline \multirow{2}{*}{\multicolumn{2}{|c|}{ Mocel }} & \multicolumn{2}{|c|}{ Unstandardeed Coeticients } & \multirow{2}{*}{$\begin{array}{c}\text { Standsedzed } \\
\text { Coeficients } \\
\text { Becs }\end{array}$} & \multirow[b]{2}{*}{$t$} & \multirow[b]{2}{*}{ Sig } & \multicolumn{2}{|c|}{95.03 Configence inderval for 8} \\
\hline & & 8 & S9d Ertot & & & & Lowet Bound & Uppet Bound \\
\hline \multirow[t]{7}{*}{1} & (Coestant) & .818 & 639 & & -1281 & 203 & .2087 & 450 \\
\hline & Oencer & 110 & 374 & .025 & 284 & 769 & .632 & 852 \\
\hline & edu & $m 7$ & 121 & 205 & 2299 & 024 & 038 & 517 \\
\hline & old & $.1745 E .5$ & 011 & .000 & .002 & 999 & .021 & .021 \\
\hline & Employmant & 370 & 127 & 250 & 2918 & 004 & 118 & 621 \\
\hline & incorre & $\infty 00$ & 000 & 174 & 1984 & 083 & 000 & 001 \\
\hline & ares & 014 & .004 & 320 & 3348 & .001 & 006 & 023 \\
\hline
\end{tabular}

a Dependent Variable: Preservation of current landuse.
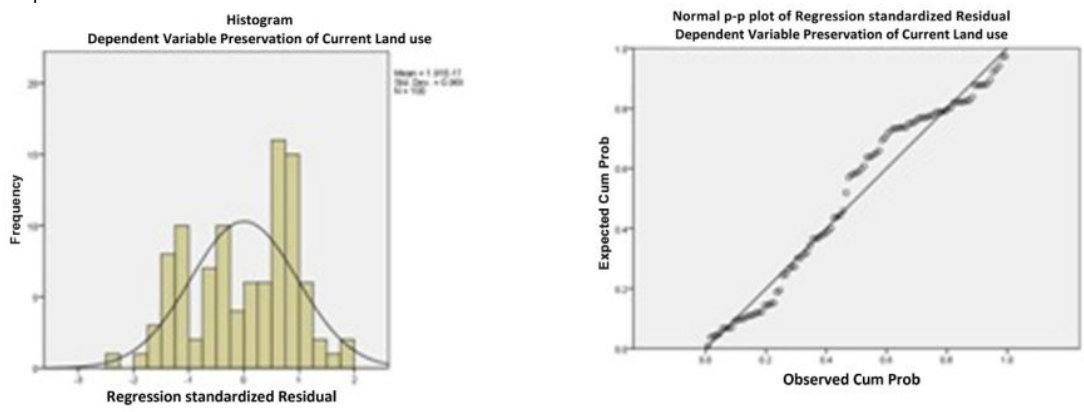

Figure 14e. Multiple regression analysis with attitude as the dependent variable in urban sprawl fringes of Tamya city.

\section{Coefficients $^{\mathrm{a}}$}

\begin{tabular}{|c|c|c|c|c|c|c|c|c|}
\hline \multirow[b]{2}{*}{ Mod } & & \multicolumn{2}{|c|}{ Unstandardces Coefficionts } & \multirow{2}{*}{$\begin{array}{c}\text { Standardaed } \\
\text { Coenticien's } \\
\text { Beta }\end{array}$} & \multirow[b]{2}{*}{$t$} & \multirow[b]{2}{*}{$\operatorname{sig}$} & \multicolumn{2}{|c|}{$95.0 x$ Confdence inserval soe 8} \\
\hline & & $B$ & Std Ertor & & & & Lower Bound & Upper Bound \\
\hline \multirow[t]{7}{*}{1} & (Consturo) & .877 & 587 & & -1.152 & 252 & -1.844 & 490 \\
\hline & Gender & 075 & 328 & 019 & 230 & 819 & .576 & 726 \\
\hline & edu & 372 & 104 & 309 & 3590 & .001 & .166 & 578 \\
\hline & ang & $\infty 00$ & 010 & .003 & .041 & 968 & .021 & 020 \\
\hline & Emcloyment & 270 & .122 & .183 & 2205 & 030 & 027 & 513 \\
\hline & income & $\infty$ & 000 & 145 & 1.629 & 107 & .000 & .001 \\
\hline & atea & 014 & .006 & 322 & 3.591 & 001 & 006 & 022 \\
\hline
\end{tabular}

a Dependent Variable: Preservation of current landuse.
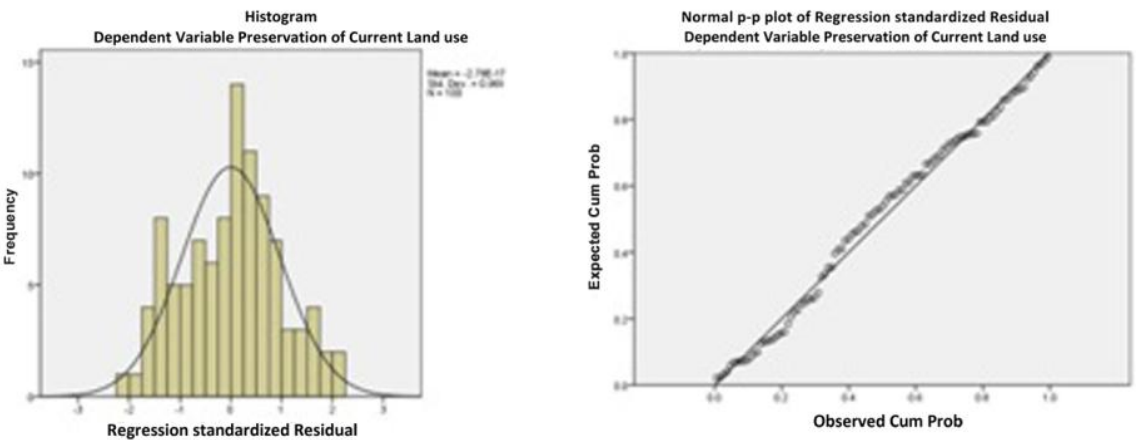

Figure 14f. Multiple regression analysis with attitude as the dependent variable in urban sprawl fringes of Ebshway city. 
Coefficients $^{\mathrm{a}}$

\begin{tabular}{|c|c|c|c|c|c|c|c|c|}
\hline \multirow[b]{2}{*}{ Mod: } & & \multicolumn{2}{|c|}{ Unstandardzed Coeffrisints } & \multirow{2}{*}{$\begin{array}{l}\text { Seandardeed } \\
\text { Cooficients } \\
\text { Beta }\end{array}$} & \multirow[b]{2}{*}{$t$} & \multirow[b]{2}{*}{ sig. } & \multicolumn{2}{|c|}{$950 \times$ Comdence interval for 8} \\
\hline & & B & Std Error & & & & Lowet Bound & Uppet Bound \\
\hline \multirow[t]{7}{*}{1} & (Constarlo & .818 & .639 & & .1 .281 & 203 & .2087 & 450 \\
\hline & Gender & .110 & .374 & 025 & 294 & .769 & .632 & 852 \\
\hline & edu & 277 & .121 & 205 & 2.299 & 068 & .038 & 517 \\
\hline & old & $-1.745 E-5$ & 011 & 000 & .002 & 999 & .021 & 021 \\
\hline & Employment & .370 & .127 & 250 & 2.918 & .007 & .118 & .621 \\
\hline & income & .000 & .000 & .174 & 1804 & OS3 3 & .000 & .001 \\
\hline & area & 014 & 000 & 320 & 3348 & 001 & .006 & 023 \\
\hline
\end{tabular}

a Dependent Variable: Preservation of current landuse.
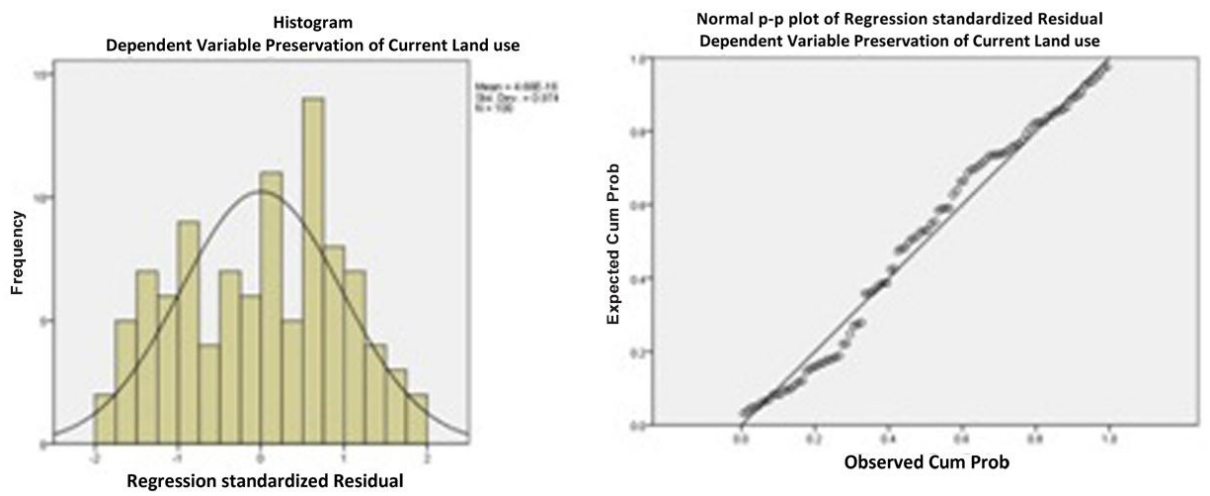

Figure 14g. Multiple regression analysis with attitude as the dependent variable in urban sprawl fringes of Yosef El Sediq city.

\subsubsection{Residents' behavioral intention towards landuse development}

Beside to the analysis of the responses to the aforementioned questions deal with residents' behavior towards development around their residences, the study includes another question deals with the residents' attitude towards the development of their parcels in the future: "What percentage chance you think that you could develop this parcel use or sell it to another who develop it?" (Appendix 1). The residents' responses to this question have categorized into three categories as follow: the lower chance (less than $30 \%$ ), the middle chance (30 to $60 \%$ ) and the higher chance (greater than 60\%). Table (7) demonstrates that generally great percentage of residents report less than 30 percentage chance for development of their property (Yosef El Sediq comes first of this category while Etsa comes last). People who responded mid percent chance (30:60\%) present $28.2 \%$ which varying between cities. About $10.9 \%$ of residents responded that they may intend to develop their property except Etsa where $19.1 \%$ of residents report that. 
Table 7. Probability of develop the property.

\begin{tabular}{|c|c|c|c|c|c|c|c|}
\hline $\begin{array}{c}\text { Chance of } \\
\text { Development }\end{array}$ & 量 & 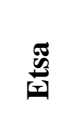 & 象 & 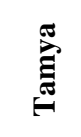 & $\frac{\vec{E}}{\frac{\vec{E}}{\Delta}}$ & 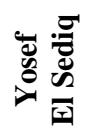 & 范 \\
\hline less than $30 \%$ & 62.1 & 45.4 & 64 & 64 & 61.9 & 68.2 & 60.9 \\
\hline 30 to $60 \%$ & 30.7 & 35.5 & 27.7 & 28.1 & 26.9 & 20 & 28.2 \\
\hline greater than $60 \%$ & 7.2 & 19.1 & 8.3 & 7.9 & 11.2 & 11.8 & 10.9 \\
\hline
\end{tabular}

\subsubsection{The logistic regression analysis}

Logistic regression (LR) is statistical modeling method for categorical data. first, it used in biomedical research. Then it is expanded to a various fields (Meyers, 2013). It's mainly depends upon two broad applications in applied research: classification (predicting group membership) and profiling (differentiating between two groups based on certain factors) (Tansey, 1996).

The SPSS logistic regression feature was chosen as an appropriate statistical method for testing equations with people psychological satisfaction of current landuse allocation, their trends towards preservation of current landuse as a dependent variable. Accordingly, This dependent variable was coded (0.1). A value of zero means that is unlikely to occur, whereas a value of one means that it is very likely to occur. The results of the analysis on all cities level (Tables 8 a-g) reveal that, householders education, old, employment status and parcel area are all positively related to residents' trends towards preservation of current landuse where there is a statistical significance. for each one unit increase in education, the odds of preservation of current landuse are 1.481 times greater. While the odds of preservation of current landuse are 1.021 times greater for each one unit increase in old, 1.275 in employment status and 0.995 times greater for each one unit increase in parcel area.

The logistic regression analysis results on the city level demonstrates that householder education may be only a predictor to trend towards preservation of current landuse in Tamya fringes. It associated with householder old in Fayoum city fringes, when it comes accompanied by the employment in Sonorus fringes. Employment with parcel area may consider as the predictors in Ebshway fringes, monthly income is in Etsa. While there is no any significant correlations in Yosef El Sediq. 
Table 8a. Logistic regression analysis with preservation as the dependent variable in urban sprawl fringes of Fayoum cities.

Variables in the Equation

\begin{tabular}{|c|c|c|c|c|c|c|c|}
\hline & & $B$ & S.E. & Wald & df & Sig. & $\operatorname{Exp}(B)$ \\
\hline \multirow[t]{7}{*}{ Step $1^{a}$} & Gender & -.449 & .276 & 2.633 & 1 & .105 & .639 \\
\hline & edu_A & .393 & .084 & 22.006 & 1 & .021 & 1.481 \\
\hline & old_A & .021 & .008 & 6.791 & 1 & .009 & 1.021 \\
\hline & Employment_A & .243 & .096 & 6.451 & 1 & .011 & 1.275 \\
\hline & income_A & .000 & .000 & 1.935 & 1 & .164 & 1.000 \\
\hline & area_B & -.005 & .003 & 2.716 & 1 & .099 & .995 \\
\hline & Constant & -1.258 & .515 & 5.975 & 1 & .015 & .284 \\
\hline
\end{tabular}

a. Variable(s) entered on step 1: Gender, edu_A, old_A, Employment_A, income_A, area_B.

Table 8b. Logistic regression analysis with preservation as the dependent variable in urban sprawl fringes of Fayoum city.

Variables in the Equation

\begin{tabular}{|c|c|c|c|c|c|c|c|}
\hline & & $\mathrm{B}$ & S.E. & Wald & $\mathrm{df}$ & Sig. & $\operatorname{Exp}(B)$ \\
\hline \multirow[t]{7}{*}{ Step $1^{a}$} & Gender & -.528 & .707 & .558 & 1 & .455 & .590 \\
\hline & edu_A & .610 & .223 & 7.503 & 1 & .006 & 1.841 \\
\hline & old_A & .043 & .022 & 3.685 & 1 & .055 & 1.044 \\
\hline & Employment_A & .120 & .242 & .244 & 1 & .621 & 1.127 \\
\hline & income_A & .000 & .000 & .084 & 1 & .772 & 1.000 \\
\hline & area_B & -.003 & .008 & .201 & 1 & .654 & .997 \\
\hline & Constant & -2.013 & 1.331 & 2.288 & 1 & .130 & .134 \\
\hline
\end{tabular}

a. Variable(s) entered on step 1: Gender, edu_A, old_A, Employment_A, income_ $A_{1}$ area_B.

Table 8c. Logistic regression analysis with preservation as the dependent variable in urban sprawl fringes of Etsa city.

Variables in the Equation

\begin{tabular}{|c|c|c|c|c|c|c|c|}
\hline & & $\mathrm{B}$ & S.E. & Wald & $\mathrm{df}$ & Sig. & $\operatorname{Exp}(B)$ \\
\hline \multirow[t]{7}{*}{ Step $1^{a}$} & Gender & -1.255 & .835 & 2.257 & $\overline{1}$ & .133 & .285 \\
\hline & edu_A & .339 & .207 & 2.686 & 1 & .101 & 1.403 \\
\hline & old_A & .028 & .022 & 1.575 & 1 & .209 & 1.028 \\
\hline & Employment_A & -.059 & .242 & .059 & 1 & .808 & .943 \\
\hline & income_A & -.001 & .000 & 4.432 & 1 & .035 & .999 \\
\hline & area_B & .002 & .008 & .072 & 1 & .789 & 1.002 \\
\hline & Constant & .791 & 1.358 & .339 & 1 & .560 & 2.205 \\
\hline
\end{tabular}

a. Variable(s) entered on step 1:Gender, edu_A, old_A, Employment_A, income_A, area_B. 
Table 8d. Logistic regression analysis with preservation as the dependent variable in urban sprawl fringes of Sonorus city.

Variables in the Equation

\begin{tabular}{|cl|r|r|r|r|r|r|}
\hline & \multicolumn{1}{c|}{ B } & \multicolumn{1}{c|}{ S.E. } & \multicolumn{1}{c|}{ Wald } & \multicolumn{1}{c|}{ df } & \multicolumn{1}{c|}{ Sig. } & Exp(B) \\
\hline Step 1 & Gender & -.327 & .688 & .225 & 1 & .635 & .721 \\
& edu_A & .461 & .216 & 4.561 & 1 & .033 & 1.586 \\
& old_A & .021 & .021 & .966 & 1 & .326 & 1.021 \\
Employment_A & .602 & .252 & 5.722 & 1 & .017 & 1.825 \\
income_A & .001 & .000 & 3.415 & 1 & .065 & 1.001 \\
area_B & -.011 & .008 & 2.104 & 1 & .147 & .989 \\
Constant & -2.494 & 1.325 & 3.543 & 1 & .060 & .083 \\
\hline
\end{tabular}

a. Variable(s) entered on step 1: Gender, edu_A, old_A Employment_ $A_{1}$ income_ $A_{1}$ area_B.

Table 8e. Logistic regression analysis with preservation as the dependent variable in urban sprawl fringes of Tamya city.

Variables in the Equation

\begin{tabular}{|ll|r|r|r|r|r|r|}
\hline & \multicolumn{1}{c|}{ B } & \multicolumn{1}{c|}{ S.E. } & \multicolumn{1}{c|}{ Wald } & \multicolumn{1}{c|}{ df } & \multicolumn{1}{c|}{ Sig. } & \multicolumn{1}{c|}{ Exp(B) } \\
\hline Step 1 & Gender & -.031 & .701 & .002 & 1 & .965 & .970 \\
& edu_A & .879 & .254 & 11.956 & 1 & .001 & 2.408 \\
& old_A & .031 & .021 & 2.056 & 1 & .152 & 1.031 \\
Employment_A & .151 & .248 & .373 & 1 & .541 & 1.163 \\
income_A & .000 & .000 & .582 & 1 & .446 & 1.000 \\
area_B & -.004 & .008 & .281 & 1 & .596 & .996 \\
Constant & -2.835 & 1.404 & 4.079 & 1 & .043 & .059 \\
\hline
\end{tabular}

a. Variable(s) entered on step 1: Gender, edu_A, old_A, Employment_A, income_A, area_B.

Table 8f. Logistic regression analysis with preservation as the dependent variable in urban sprawl fringes of Ebshway city.

Variables in the Equation

\begin{tabular}{|c|c|c|c|c|c|c|c|}
\hline & & $\mathrm{B}$ & S.E. & Wald & $\mathrm{df}$ & Sig. & $\operatorname{Exp}(B)$ \\
\hline \multirow[t]{7}{*}{ Step $1^{a}$} & Gender & -.815 & .759 & 1.153 & 1 & .283 & .443 \\
\hline & edu_A & .196 & .213 & .854 & 1 & .355 & 1.217 \\
\hline & old_A & -.006 & .021 & .089 & 1 & .766 & .994 \\
\hline & Employment_A & .845 & .269 & 9.905 & 1 & .002 & 2.328 \\
\hline & income_A & .001 & .000 & 2.010 & 1 & .156 & 1.001 \\
\hline & area_B & -.016 & .008 & 3.710 & 1 & .054 & .984 \\
\hline & Constant & -.369 & 1.328 & .077 & 1 & .781 & .691 \\
\hline
\end{tabular}

a. Variable(s) entered on step 1: Gender, edu_A, old_A, Employment_A, income_A, area_B. 
Table 8g. Logistic regression analysis with preservation as the dependent variable in urban sprawl fringes of Yosef El Sediq city.

\begin{tabular}{|c|c|c|c|c|c|c|c|}
\hline \multicolumn{8}{|c|}{ Variables in the Equation } \\
\hline & & $\bar{B}$ & S.E. & Wald & $\overline{d f}$ & Sig. & $\operatorname{Exp}(B)$ \\
\hline \multirow[t]{7}{*}{ Step $1^{a}$} & Gender & -.031 & .701 & .002 & 1 & .965 & .970 \\
\hline & edu_A & .879 & .254 & 11.956 & 1 & .001 & 2.408 \\
\hline & old_A & .031 & .021 & 2.056 & 1 & .152 & 1.031 \\
\hline & Employment_A & .151 & .248 & .373 & 1 & .541 & 1.163 \\
\hline & income_A & .000 & .000 & .582 & 1 & .446 & 1.000 \\
\hline & area_B & -.004 & .008 & .281 & 1 & .596 & .996 \\
\hline & Constant & -2.835 & 1.404 & 4.079 & 1 & .043 & .059 \\
\hline
\end{tabular}

a. Variable(s) entered on step 1: Gender, edu_A, old_A, Employment_A, income_A, area_B.

\section{Discussion}

The statistical analysis of the study present a good indication of the impact of householders attitudes that considered the main driver of their behavior towards landuse decision in Fayoum cities fringes. Comparing the results could assist in evaluating landuse decisions and in predicting the possible successful implementation of landuse allocation plans in Fayoum cities outskirts. More than $60 \%$ of residents have lived in these fringes for 10 years and more who satisfy with this amount of land development and feel that is no need to any further development.

The current landuse image showed that there is prevailing of residential non-mixed use followed by that mixed with commercial and industrial uses generally in all Fayoum cities fringes as result to land price cheapness, seeking better life opportunities and establishing small projects.

According to results of multiple regression analysis implemented using a dependent variable of attitude towards landuse development, parcel area, employment, monthly income and education emerged as main predictors while varied among cities fringes.

The analysis of the residents' attitude towards the development of their parcels in the future proved that greater percentage of people thought they will have the minimum chances for development of their property, followed by People who had mid percent chance of development.

The use of the Logistic regression Model (LRM) to assist in awareness of the main predictor to adopting the idea of preservation of current landuse is well established. It demonstrated that householder education level, old, 
employment and owned area can be considered as predictors for residents trends towards preservation of current landuse or not.

\section{Conclusion}

Urban landuse is generally anticipated to expand with the continually increasing urban population. The private landuse patterns are affected by several factors which control the land owners decisions. Factors which motivate the landuse decisions are mainly responsible of the varying landuse types and they differ from person to another and from one city to another as a result of different circumstances.

The random and unmanaged urban growth fringes of Fayoum cities have their landuse allocation problems, which are in need to identity their main reasons, from the standpoint of residents' attitudes towards landuse development (LUD).

Understanding the moderators that drive land owner decisions to choose or change the landuse is crucial. This paper demonstrates people's reasons to live at these areas in addition to introduce an advanced statistical method for improving this understanding by investigating the impact of land owners' various socioeconomic and demographic characteristic on his/her attitude towards landuse development (LUD) and which of them can predict landuse future distribution. Several predictors were emerged in various cities based on changes in socioeconomic and demographic as independent variables and by applying two types of regressions.

In light of the critical need to make an effective and implementable strategic urban landuse plan, the study would recommend incorporate the behavioral approach, GIS, RS techniques and the statistical methods within studies of landuse allocation in Egypt. 


\section{Appendix 1}

\section{Questionnaire of Fayoum cities urban sprawl fringes}

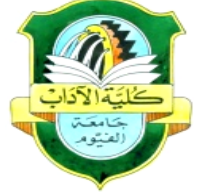

Fayoum University

Faculty of Arts

City:

Sector:

Building ID:

\section{Building Characteristics:}

Building types: rural $\square \quad$ individual house $\square \quad$ apartment $\square \quad$ apartment block $\square$ other $\square$

$\begin{array}{llll}\text { Building material } & \text { adobe } \square & \text { loam bricks } & \text { lime bricks } \square \\ \text { Building status } \quad \text { good } \square & \text { middle } \square & \text { bad } \square \\ \text { Accessibility to infrastructure } & \text { water } \square & \text { drainage } \square \\ \text { ownership status } & \text { land owner } \square & \text { tenant } \square \\ \text { Landuse pattern } & \text { residential } \square & \text { mixed res./ind. } \square \\ & \text { mixed res./com. } \square & \text { commercial } \square \\ & \text { industrial } \square & \text { services } \square\end{array}$

\section{Socioeconomic and Demographic Characteristics:}

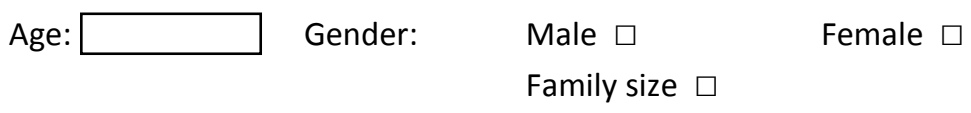

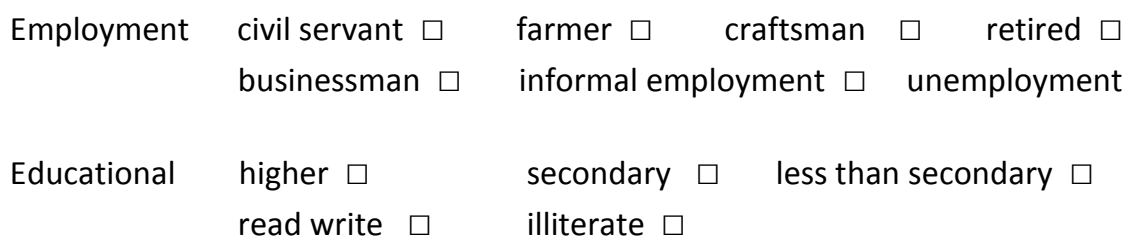

$\begin{array}{llll}\text { Family income } & <£ 500 \square & £ 500-\square & £ 1000-\square \\ & £ 1500-\square & £ 2000-\square & £ 2500+\square\end{array}$




\section{Fringes land occupancy:}

Please estimate the influence of the factors below in your decision to establish this land use at this area using the following scale : $0=$ "No influence", 1="Medium influence", $2=$ "High influence"

Reason for land $\quad$ use cheaper land $\square \quad$ establish an economic project $\square$ better living $\square \quad$ investment $\square \quad$ highway access municipal water/drainage availability topography and aesthetic

How long have you lived in this place?

$\begin{array}{llll} & <5 \mathrm{y} . \quad \square & 5-10 \mathrm{y} . \square & >10 \mathrm{y} . \square \\ \text { property area } & <150^{\mathrm{sq}} \mathrm{m} . \quad \square & 150-300^{\mathrm{sq}} \mathrm{m} . \square & >300^{\mathrm{sq}} \mathrm{m} .\end{array}$

How do you feel about the amount of developed land (for example, residential, commercial and other uses) that currently exist within approximately $1^{\text {sq. }}$ kilometer of this parcel?

$\begin{array}{lll}\text { too much } \square & \text { probably too much } \square & \text { the right amount } \\ \text { probably too little } \square & \text { too little } \square & \text { don't know } \square\end{array}$

"What percentage chance you think that you could change this parcel use or sell it to another who change it??

$$
<30 \% \square 30: 60 \% \quad \square \quad>60 \%
$$

would you like to participate in a governmental program to change landuse activities if it is available?

Definitely

maybe

maybe no

definitely no

don't know 


\section{REFERENCES}

1. Adelman, I., 2007, "Fallacies in Development Theory and Their Implications for Policy", In Frontiers of Development Economics: Washington DC \& Oxford, The World Bank \& Oxford University Press.

2. Braun, J.V., 2007, Rural-Urban Linkages for Growth, Employment, and Poverty Reduction in Association, E.E., ed., Fifth International Conference on the Ethiopian Economy United Nations Conference Center, Addis Ababa Keynote.

3. Buttel, F.H.a.W.L.F., 1977, Conceptions of rural life and environmental concern. Rural Sociology, Vol. 42, pp. 44-55.

4. Corraliza, J.A.a.J.B., 2000, Environmental values, beliefs, and actions: a situational approach: Environment and Behavior. Vol. 32, pp. 832-848.

5. Eiser, J.R.a.J.v.d.P., 1988, Attitudes and decisions. London, Routeledge.

6. Fortman, L.a.J.K., 1990, New voices, old beliefs: forest environmentalism among new and long-standing rural residents: Rural Sociology. Vol. 55, pp. 214-232.

7. Fulton, D.C., M.J. Manfredo and J. Lipscomb, 1996, Wildlife value orientations: A conceptual and measurement approach. Human Dimensions of Wildlife, Vol. 1, pp. 24-47.

8. Gong, P., and P.J. Howarth, 1992, Frequency-based contextual classification and graylevel vector reduction for landuse identification. Photogrammetric Engineering \& Remote Sensing, Vol. 58, pp. 423-437.

9. Gray, D.B., R.J. Borden and R.H. Weigel, 1985, Ecological beliefs and behaviors: Assessment and change: Westport, Connecticut, Greenwood Press.

10. Hedwig van Delden, G.M., Yu-e Shi, Jelle Hurkens, Jasper van Vliet, and Marjan van den Belt, 2011, Integrating socio-economic and landuse models to support urban and regional planning. Ecological Economics Research.

11. Jensen, J., 2000, Remote sensing of the environment: an earth resource perspective: Saddle River, Prentice Hall.

12. Koontz, T.M., 1999, Targeting landuse policy: identifying parcels most susceptible to different landuses. Better Ways to Develop Ohio Conference Columbus, Ohio.

13. Laubhan, M.K.a.J.H.G., 2001, Agricultural producers' perceptions of sand hill cranes in the San Luis Valley of Colorado. Wildlife Society Bulletin, Vol. 29 pp. 639-645.

14. Lowe, G.D.a.T.K.P., 1982, Rural-urban differences in support for environmental protection. Rural Sociology, Vol. 47, pp. 114-128.

15. McBeth, M.K., 1995, Rural environmental and economic development attitudes: an empirical analysis. Economic Development Quarterly, Vol. 9 pp. 39-41.

16. Meyers, L.S., Gamst, G., \& Guarino, A.J, 2013, Applied Multivariate Research: Design and Interpretation Thousand Oaks, CA, Sage Publications.

17. NCHRP, 1998, Guidance for Estimating the Indirect Effects of Proposed Transportation Projects, NCHRP Report 403: Washington, DC.

18. Research scholar, D.O.E., 2013, in Science, H.A.S., ed., Volume 10(5): Kasaragod, Kerala, India Department of Economics, Central University of Kerala, pp. 12-24.

19. Rosenberg, M.J.a.H., C.I., Eds., 2010, Attitude Organization and Change: An Analysis of Consistency among Attitude Components. New Haven, Yale University Press.

20. Safey El Deen, M., 1999, Morphology of The Egyptian Lands. Dar Ghareeb for printing, publishing and distribution, Cairo, Egypt. 
21. Sanchez, T.a.T.M., 2000, "Indirect Landuse and Growth Impacts of Highway Improvements: Phase 1 Report" Washington, DC Oregon Department of Transportation Research Group and Federal Highway Administration.

22. Scott, D.a.F.K.W., 1994, Attitudes and behavior: A Pennsylvania survey. Environment and Behavior, Vol. 26, pp. 239-260.

23. Smith, M.D.a.R.S.K., 2000, clash revisited: newcomer and longer-term residents. attitudes toward landuse, development, and environmental issues in rural communities in the Rocky Mountain West. Rural Sociology, Vol. 56, pp. 396-421.

24. Stern, P.C., 2000, Toward a coherent theory of environmentally significant behavior. Journal of Social Issues, Vol. 56, pp. 407-424.

25. Tansey, R., M. White, \& R. Long 1996, A comparison of log linear modeling and logistic in management research. Journal of management, Vol. 22, pp. 339-358.

26. Tremblay, R.K.a.R.E.D., 1978, Rural-urban residence and concern with environmental quality: A replication and extension. Rural Sociology, Vol. 43, pp. 474-491.

27. Vaske, J.J., \& Donnelly, M.P, 1999, A value-attitude-behavior model predicting wild land preservation voting intentions. Society and Natural Resources, Vol. 12, pp. 523-537.

28. Venables, A., 1996, Trade policy, cumulative causation, and industrial development. Journal of Development Economics, Vol. 49, pp. 179-98.

29. Verburg, P.H., W.T. de Groot, and A.J. Veldkamp, 2003, Methodology for multiscale landuse change modeling: concepts and challenges." In Global environmental change and landuse, eds. A.J. Dolman, A. Verhagen and C.A. Rovers. Boston, Kluwer Academic Publishers.

30. William H. Friedland, 2002, Agriculture and Rurality: Beginning the "Final Separation”. Rural Sociology, Vol. 67, pp. 350-371. 